Acta vet. scand. $1981,22,289-295$.

From the Department of Pathology, College of Veterinary Medicine, Helsinki, Finland.

\title{
THE INFLUENCE OF DIETARY MOLYBDENUM AND COPPER SUPPLEMENTATION ON THE CONTENTS OF SERUM URIC ACID AND SOME TRACE ELEMENTS IN COCKS
}

By

\author{
M. Karring, R. Pohjanvirta, T. Rahko and H. Korpela
}

KARRING, M., R. POHJANVIRTA, T. RAHKO and H. KORPELA: The influence of dietary molybdenum and copper supplementation on the contents of serum uric acid and some trace elements in cocks. Acta vet. scand. 1981, 22, 289 - 295. - The effect of molybdenum (Mo) and copper $(\mathrm{Cu})$ supplementation on some blood parameters and trace elements of tissues of cocks was investigated. The animals were fed with commercial poultry feed and water ad libitum and the experimental groups received peroral supplementation of different amounts of Mo or $\mathrm{Cu}$ during 4 weeks. Lowered values of serum uric acid were established in animals receiving $400 \mu \mathrm{g}$ supplementation of either Mo or $\mathrm{Cu}$. In contrast, the cocks receiving $100 \mu \mathrm{g}$ supplementation of $\mathrm{Cu}$ displayed elevated concentrations of uric acid in the serum. A very significant statistical difference was noted between the uric acid levels of the animals receiving either moderate (group IV) or excess (group V) supplementation of $\mathrm{Cu}$. The cocks with an excess of $\mathrm{Cu}$ displayed lowered hemoglobin and hematocrit values but no signs of $\mathrm{Cu}$-intoxication were found in macro- and microscopical studies. Atomic absorption spectrophotometry was employed in the determinations of the content of $\mathrm{Mo}, \mathrm{Cu}, \mathrm{Zn}, \mathrm{Mn}, \mathrm{Fe}$ and $\mathrm{Se}$ in the liver and kidneys of the cocks. The authors suggest that the results of the trace element analyses presented are to be considered as preliminary values. Furthermore, the effect of Mo and Cu on uric acid metabolism should be additionally clarified by applying histochemical studies on xanthine oxidase in different tissues of cocks in order to make conclusions on the significance of $\mathrm{Mo}$ and $\mathrm{Cu}$ in the etiology of avian gout.

molybdenum; copper; uric acid; poultry.

Xanthine oxidase is an iron and molybdenum-containing enzyme of the purine metabolism, whose function is to catalyze the formation of uric acid from xanthine. The increase in the activity of xanthine oxidase is followed by an elevation in the concentration of serum uric acid, thus causing disposition to gout (Hall et al. 1967, Olson et al. 1974, Pohjanvirta et al. 1979). 
Previous studies have shown that changes of the copper and molybdenum ratio cause changes in the formation of uric acid in the rat (Kovalsky \& Vorotnitskaya 1970). The purpose of this investigation was to clarify if the dietary supplementation of these trace elements influences the concentrations of serum uric acid and some trace elements in poultry.

\section{MATERIAL AND METHODS}

Thirty clinically healthy cocks aged 12 weeks of the white leghorn race were randomly divided into 5 groups with 6 animals in each group. They were fed commercial poultry feed (KasvatusPunaheltta, Vaasan Höyrymylly) and water ad libitum.

By a pharyngeal syringe a peroral supplementation of molybdenum (Mo) and copper $(\mathrm{Cu})$ in the form of a water solution of ammonium molybdate and copper sulphate was given daily during 4 weeks as follows: $400 \mu \mathrm{g}$ Mo in group I; $100 \mu \mathrm{g}$ Mo in group II; $100 \mu \mathrm{g} \mathrm{Cu}$ in group IV; $400 \mu \mathrm{g} \mathrm{Cu}$ in group V, and group III served as control, without mineral supplementation.

After 4 weeks blood samples were taken from the carotid arteries and the cocks were killed and immediately necropsied. In addition to macroscopical studies, samples of tissue were selected for histopathological studies from the liver, kidneys, heart and lungs, fixed with $10 \%$ buffered formaline solution for 2 days, embedded in paraffine, cut at $5 \mu \mathrm{m}$ and routinely stained with haematoxylin and eosin (McManus \& Mowry 1960).

The blood samples of the cocks were submitted for usual hematological and chemical studies, including hemoglobin ( $\mathrm{g} / \mathbf{1 0 0 0}$ $\mathrm{ml})$, hematocrit, creatinine $(\mu \mathrm{mol} / \mathrm{l})$, aspartate aminotransferase (E.C. 2.6.1.1., ASAT $\mu \mathrm{kat} / \mathrm{l}$ ) and alanine aminotransferase (E.C. 2.6.1.2, ALAT $\mu \mathrm{kat} / \mathrm{l})$ determinations. The concentration of uric acid in the serum of the cocks was estimated according to the enzymatic method described by Hyvärinen et al. (1972). Atomic absorption spectrophotometry was employed in the determination of the content of trace elements $(\mathrm{mg} / \mathrm{kg})$ as follows: Mo and $\mathrm{Cu}$ of the liver and kidneys of all the animals, zinc $\left(Z_{n}\right)$, manganese $(\mathrm{Mn})$ and iron $(\mathrm{Fe})$ of the liver of all the animals and selenium (Se) of the liver in only groups I, III and V.

\section{RESULTS AND DISCUSSION}

The general condition of the cocks remained good during the experiment. 
In the necropsy of the animals no differences were found in the appearance of the inner organs between the experimental and control groups. This was also the result in microscopical studies of the organs and it was concluded that the dietary supplementations of $\mathrm{Mo}$ and $\mathrm{Cu}$ to the animals did not cause observable morphological changes due to $\mathrm{Cu}$-intoxication. This conclusion was additionally confirmed by the determinations of ASAT, ALAT and creatinine values shown in Table 1. However, hemoglobin and hematocrit values showed distinct differences between the experimental and control groups. The lowest hemoglobin $(P<0.05)$ and hematocrit $(P<0.01)$ values were encountered in the animals of group $\mathrm{V}$ which had the greatest supplementation of $\mathrm{Cu}$. This finding might indicate that the excessive amount of $\mathrm{Cu}$ possibly produced a harmful effect on hematopoiesis of the cocks. However, further studies are needed to confirm this hypothesis as other results of the present investigation did not reveal changes typical of Cu-intoxication (Gratzl \& Köhler 1968).

$\mathrm{T}$ a b l e 1. Mean values \pm standard deviations of hemoglobin $(\mathrm{Hb})$, hematocrit (Hcr), aspartate aminotransferase (ASAT), alanine aminotransferase (ALAT) and creatinine (Creat) in blood samples of groups of 6 cocks receiving dietary supplementation of either molybdenum (Mo) or copper (Cu) (Group I: $400 \mu \mathrm{g}$ Mo, Group II: $100 \mu \mathrm{g} \mathrm{Mo}$, Group III: Control, Group IV: $100 \mu \mathrm{g} \mathrm{Cu}$ and Group V: $400 \mu \mathrm{g} \mathrm{Cu}$ ).

\begin{tabular}{llrrrr}
\hline & Hb & \multicolumn{1}{c}{ Hcr } & \multicolumn{1}{c}{ ASAT } & ALAT & \multicolumn{1}{c}{ Creat } \\
\hline Group I & $132 \pm 11$ & $33.3 \pm 1.3$ & $3.9 \pm 0.2$ & $1.3 \pm 0.3$ & $43.5 \pm 4.1$ \\
Group II & $138 \pm 9$ & $33.3 \pm 0.4$ & $4.4 \pm 0.2$ & $1.3 \pm 0.3$ & $45.0 \pm 3.8$ \\
Group III & $123 \pm 8$ & $31.5 \pm 0.6$ & $4.2 \pm 0.1$ & $1.3 \pm 0.1$ & $44.5 \pm 0.9$ \\
Group IV & $148 \pm 10$ & $33.3 \pm 1.4$ & $4.0 \pm 0.5$ & $\star \star 0.6 \pm 0.2$ & $47.6 \pm 6.2$ \\
Group V & $* 114 \pm 5$ & $* \star 29.0 \pm 1.0$ & $3.3 \pm 0.5$ & $1.2 \pm 0.1$ & $37.0 \pm 6.4$ \\
\hline
\end{tabular}

Significant differences between the experimental and control groups are marked with asterisks: ${ }^{\star} \mathrm{P}<0.05 ;{ }^{\star}{ }^{\star} \mathrm{P}<0.01$.

The concentration of uric acid in the serum of the cocks (Fig. 1) was distinctly affected by the dietary supplementation of Mo or $\mathrm{Cu}$. In both marginal groups fed with excessive Mo or $\mathrm{Cu}$, clearly lower values of serum uric acid were encountered, with the lowest values being in the animals of group $\mathrm{V}$ which received the highest $\mathrm{Cu}$ supplementation. The highest contents of uric acid, on the contrary, were found in group IV receiving 


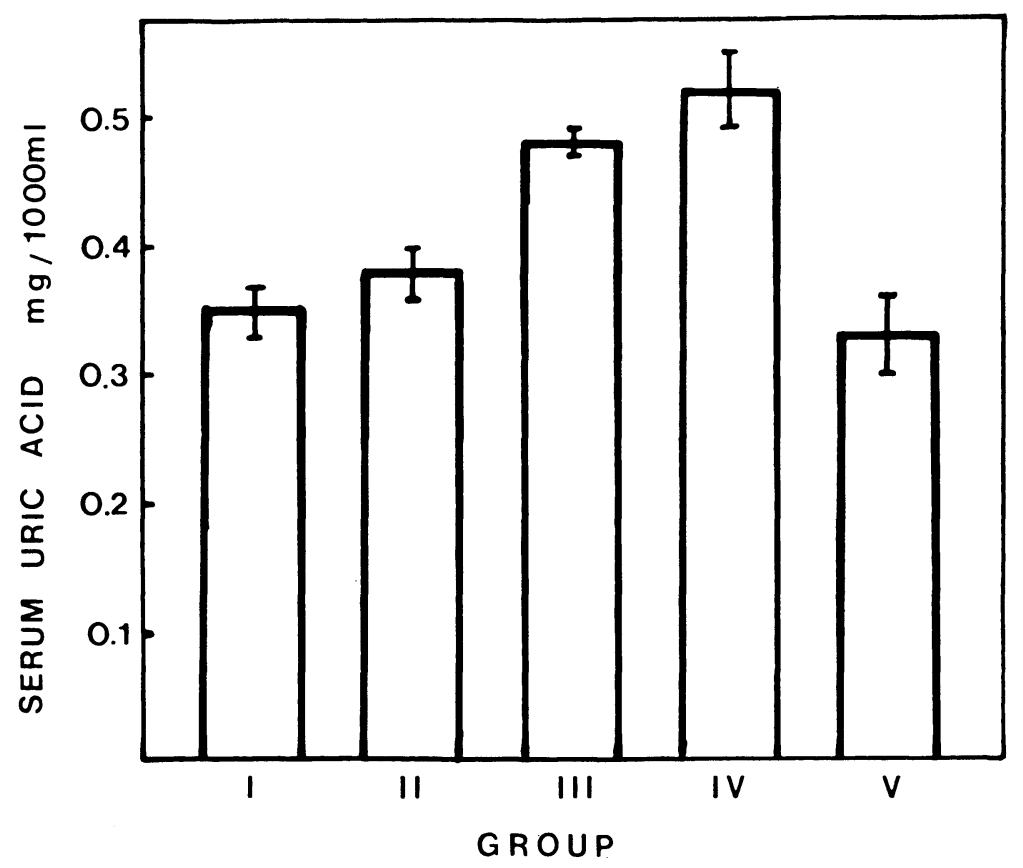

F i g u r e 1. Mean values \pm standard deviations of uric acid (mg/1000 $\mathrm{ml}$ ) in serum samples of groups of cocks receiving dietary supplementation of either molybdenum (Mo) or copper (Cu) (see text of Table 1).

a moderate $\mathrm{Cu}$ addition. Statistical analyses confirmed a highly significant difference in the concentration of uric acid between the groups IV and V $(P<0.001)$.

Previous studies in the rat have shown that the activity of xanthine oxidase is affected by changes in the dietary Mo: Cu ratio (Kovalsky \& Vorotnitskaya 1970). This is supposed to result from the presence of $\mathrm{Cu}$ and $\mathrm{Mo}$ in xanthine oxidase in this species of animal. Bovine animals are also known to possess both $\mathrm{Mo}$ and $\mathrm{Cu}$ in xanthine oxidase, but in cocks the composition of trace elements of the enzyme has not been previously clarified as far as the authors know. The relationship between $\mathrm{Mo}$ and $\mathrm{Cu}$ is antagonistic (e.g. Davies 1972, Kovalsky et al. 1973, Goodhart \& Shils 1976) and apparently therefore Cu may inhibit the activity of xanthine oxidase.

Experimental studies on the effect of Mo and Cu supplementation have dealt with mammalian animals but not fowls. Owing to differences in uric acid metabolism between these animal spe- 
cies, the result of the present study cannot be adequately compared with other studies. However, many similarities are to be noted in the metabolic response of the rat (Kovalsky \& Vorotnitskaya 1970) and of the cocks to the dietary minerals studied.

On completion of the present experiment the amounts of Mo and $\mathrm{Cu}$ in samples of the commercial feed were analyzed. The analysis showed the presence of about $0.51 \mathrm{mg} / \mathrm{kg} \mathrm{Mo}$ and 9.8 $\mathrm{mg} / \mathrm{kg} \mathrm{Cu}$ in the samples. Due to the unexpected great difference in the contents of these elements in the feed, the supplementation of $\mathrm{Mo}$ and $\mathrm{Cu}$ of the same quantities did not produce grave changes between the $\mathrm{Mo}: \mathrm{Cu}$ ratio of the experimental groups. It appears that in future studies the Cu spplementation should be greater if commercial feed is used instead of an experimental diet devoid of these substances.

The contents of $\mathrm{Mo}, \mathrm{Cu}, \mathrm{Zn}, \mathrm{Mn}, \mathrm{Fe}$ and $\mathrm{Se}$ in the organs of the cocks in the different experimental groups are presented in Table 2. Because of the small size of the groups, the results are to be considered as only directional values.

T a b l e 2. Mean values \pm standard deviations of $\mathrm{Mo}, \mathrm{Cu}, \mathrm{Zn}, \mathrm{Mn}$ and Se $(\mathrm{mg} / \mathrm{kg})$ in tissue samples of the liver and kidneys of groups of 6 cocks receiving dietary supplementation of either molybdenum (Mo) or copper ( $\mathrm{Cu}$ ) (see the text of Table 1 ).

\begin{tabular}{|c|c|c|c|c|}
\hline & Mo liver & Mo kidney & $\mathrm{Cu}$ liver & Cu kidney \\
\hline Group I & $3.0 \pm 0.5$ & $4.0 \pm 0.3$ & $14.5 \pm 0.9$ & $12.5 \pm 0.3$ \\
\hline Group II & $3.0 \pm 0.0$ & $3.8 \pm 0.2$ & $14.7 \pm 1.1$ & $12.0 \pm 0.3$ \\
\hline Group III & $3.3 \pm 0.5$ & $3.8 \pm 0.2$ & $14.2 \pm 1.1$ & $10.8 \pm 0.4$ \\
\hline Group IV & $2.5 \pm 0.3$ & $4.5 \pm 0.3$ & $13.5 \pm 0.4$ & $11.5 \pm 0.3$ \\
\hline \multirow[t]{2}{*}{ Group V } & $2.7 \pm 0.4$ & $4.0 \pm 0.3$ & $13.2 \pm 1.3$ & $11.3 \pm 0.3$ \\
\hline & Zn liver & Mn liver & Fe liver & Se liver \\
\hline Group I & $104.3 \pm 5.3$ & $13.2 \pm 0.7$ & $805 \pm 141$ & $2.8 \pm 0.2$ \\
\hline Group II & $103.0 \pm 4.4$ & $14.3 \pm 0.9$ & $870 \pm 79$ & - \\
\hline Group III & $104.3 \pm 9.7$ & $15.3 \pm 2.0$ & $648 \pm 71$ & $2.9 \pm 0.3$ \\
\hline Group IV & $102.5 \pm 3.0$ & $13.8 \pm 0.9$ & $837 \pm 171$ & $-\quad-$ \\
\hline Group V & $97.2 \pm 7.8$ & $12.7 \pm 0.7$ & $805 \pm 94$ & $4.0 \pm 0.3$ \\
\hline
\end{tabular}

Nevertheless, the preliminary observations made should be thoroughly studied. The significance of the high values of Se in cocks with high $\mathrm{Cu}$ amounts in their diets especially need further studies in order to be elucidated. 


\section{CONCLUSIONS}

The studies described in this paper on the influence of dietary molybdenum (Mo) and copper ( $\mathrm{Cu}$ ) supplementation on the concentration of uric acid in the serum of cocks showed a dependance between the degree of supplementation of the trace elements and the uric acid level. The experiments revealed lowered values of serum uric acid in groups receiving $400 \mu \mathrm{g}$ addition of either Mo or $\mathrm{Cu}$ but elevated values in the cocks receiving $100 \mu \mathrm{g} \mathrm{Cu}$ supplementation in the diet. A statistical difference $(P<0.001)$ existed between the uric acid concentrations of animal groups receiving moderate or excess $\mathrm{Cu}$ supplementation.

In hematological studies lowered hemoglobin and hematocrit values were established in animal groups with excess $\mathrm{Cu}$ supplementation, but otherwise the results concerning the usual hematological determinations and macro- and microscopical studies appeared normal. The determinations of $\mathrm{Mo}, \mathrm{Cu}, \mathrm{Zn}, \mathrm{Mn}, \mathrm{Fe}$ and Se in some organs of the experimental animals are to be considered as preliminary results, due to the small size of the groups, but give rise to further studies.

\section{REFERENCES}

Davies, I. J. T.: The Clinical Significance of the Essential Biological Metals. William Heinemann Books Ltd, London 1972.

Goodhart, R. S. \& N. E. Shils: Modern Nutrition in Health and Disease. Dietotherapy. Lea \& Febiger, 5th ed., Philadelphia 1976.

Gratzl, E. \& H. Köhler: Spezielle Pathologie und Therapie der Geflügelkrankheiten. (Special Pathology and Therapy of Avian Diseases). Ferdinand Enke Verlag, Stuttgart 1968.

Hall, A. P., P. E. Barry, T. R. Dawber \& P. M. McNamara: Epidemiology of gout and hyperuricemia: A longterm population study. Amer. J. Med. 1967, 42, 27-37.

Hyvärinen, A., J. Jännes, E. Nikkilä, N.-E. Saris \& P. Vuopio: Kliiniset Laboratoriotutkimukset. (Clinical Laboratory Studies). WSOY, Helsinki 1972, p. 412.

Kovalsky, V. V.\& I. E. Vorotnitskaya: Induction of the enzymes of purine metabolism by copper and molybdenum. In Trace Element Metabolism in Animals. Ed. C. F. Mills. E. \& S. Livingstone, Edinburgh and London 1970, pp. 176-179.

Kovalsky, V. V., I. E. Vorotnitskaya \& G. G. Tsoi: Adaptive changes of the milk xanthine oxidase and its isoenzymes during molybdenum and copper action. In Trace Element Metabolism in Animals. 2. Eds. W. G. Hoekstra, J. W. Suttie, H. E. Canther \& W. Mertz. University Park Press, Baltimore 1973, pp. 161-170. 
McManus, J. F. A. \& R. W. Mowry: Staining Methods: Histologic and Histochemical. Paul P. Hoeber, Inc., New York 1960.

Olson, J. S., D. Ballou, G. Palmer \& W. Massey: The mechanism of action of xanthine oxidase. J. biol. Chem. 1974, 249, 4363-4382.

Pohjanvirta, R., M. Karring, H. Korpela \& T. Rahko: Näkökohtia lintujen ja ihmisen kihdin etiologiasta. (Etiological aspects of human and avian gout). Suom. EläinlääkL.ehti 1979, 85, 129132.

\section{SAMMANFATTNING}

Om inverkan av dietärt molybden och koppar tillskott på halten av serums urinsyra och några spårämnen hos tuppar.

Effekten av molybden (Mo) och koppar (Co) tillskottet på ett antal blodparametrar och vävnaders spårämnes halt hos tuppar undersöktes. Djuren utfodrades med kommersiellt hönsfoder och vatten ad libitum och experimentgrupperna erhöll peroralt särskilda Mo och Cu tillskott under 4 veckor. Sänkta värden av serums urinsyra noterades hos djur, som erhöll ett $400 \mu \mathrm{g}$ stort tillskott antingen av Mo eller Cu. Däremot uppvisade tupparna, som erhöll ett Cu tillskott på $100 \mu \mathrm{g}$ ökad konsentration av urinsyra i serumet. Statistiskt mycket signifikant skillnad noterades mellan urinsyra nivåerna hos djuren, som erhöll antingen moderat eller ökat tillskott av $\mathrm{Cu}$. Tupparna med överskott av $\mathrm{Cu}$ uppvisade sänkta hemoglobin och hematokrit värden, men inga tecken på Cu förgiftning kunde påvisas medelst makro- och mikroskopiska undersökningar. Atomabsorption spektrofotometri användes för bestämning av halten av $\mathrm{Mo}, \mathrm{Cu}, \mathrm{Zn}, \mathrm{Mn}, \mathrm{Fe}$ och $\mathrm{Se}$ i tupparnas lever och njurar. Författarna antyder att resultaten av spårämnes analyserna i tabell 2 måste beaktas som preliminära värden. Dessutom måste verkan av Mo och Cu på urinsyreämnesomsättningen ytterligare utredas genom att bruka histokemiska undersökningar av xantin oxidas i olika vävnader hos tuppar för att dra slutsatser om Mo:s och $\mathrm{Cu}: \mathrm{s}$ betydelse i giktens etiologi hos fåglar.

(Received January 27, 1981).

Reprints may be requested from: T. Rahko, the Department of Pathology, College of Veterinary Medicine, Hämeentie 57, 00550 Helsinki 55, Finland. 